\title{
Politicizing Europe:
}

\section{The Challenge of Executive Discretion}

Jonathan White

LEQS Paper No. 72/2014

February 2014

\section{ISE Annual Fund}




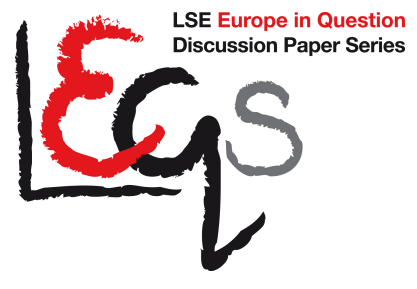

\author{
Editorial Board \\ Dr Joan Costa-i-Font \\ Dr Vassilis Monastiriotis \\ Dr Jonathan White \\ Dr Katjana Gattermann
}

All views expressed in this paper are those of the author(s) and do not necessarily represent the views of the editors or the LSE.

(C) Jonathan White 


\title{
Politicizing Europe:
}

\section{The Challenge of Executive Discretion}

\author{
Jonathan White*
}

\begin{abstract}
Political decision-making in the Euro-crisis has relied heavily on executive discretion, exercised at speed and rationalised with reference to the pressing demands of emergency. This paper explores the challenges raised for political opposition, notably challenges of a temporal kind. With its deviations from policy and procedural norms, discretionary politics tends towards a politics without rhythm, leading to major asymmetries between decisionmakers and voices of opposition. These centre on issues of timing and the ability to identify authorship and content of decisions. Such asymmetries arguably correspond to an underlying one between the temporality of political decision-making and of contemporary finance capitalism, with agents of the former increasingly inclined to pursue 'fast policy' as a means to keep pace. A democratic response is likely to involve strengthening and synchronising the rhythms of parliamentary politics, as well as being receptive to forms of opposition less reliant on the rhythms that discretion subverts.
\end{abstract}

Keywords: $\quad$ politicization, democracy, time, executive power, European Union

* Associate Professor (Reader) in European Politics, European Institute, London School of Economics and Political Science

Houghton St, London WC2A 2AE

Email: j.p.white@lse.ac.uk 


\section{Table of Contents}

Abstract

Introduction

Asymmetries of a Politics without Rhythm

Europe's Fragmented Dissent

Timing Opposition

References

\section{Acknowledgements}

Comments on a draft were kindly offered by Sara B. Hobolt, Mareike Kleine, Jan Komárek, Lea Ypi, and seminar participants at the University of Uppsala, the LSE and the Australian National University (Centre for European Studies). The text is forthcoming in Sara B. Hobolt and Olaf Cramme (2014) (eds.), Democratic Politics in a European Union under Stress (Oxford: OUP). 


\section{Politicizing Europe:}

\section{The Challenge of Executive Discretion}

\section{Introduction}

Modern political authority tends to be considered legitimate to the extent it can be openly and consequentially disputed. This is one reason why the prospects for the organised contestation of decision-making have been a recurrent theme of scholarship on the European Union (EU). Insofar as these prospects are weak, as much work on the 'democratic deficit' suggests, the EU seems anomalous, at least by the measure of our political ideals. As today's Union undergoes rapid reshaping, it is worth asking how far the outlook is changing. Are we seeing the emergence of new channels of opposition that could strengthen the contestation of EU decision-making - the emergence of a more 'politicized' order, as it is sometimes called? Or are the obstacles to such opposition proliferating, such that politicizing Europe, rather than a process in train, becomes an increasingly demanding challenge? In this paper I show how the irregular forms of decision-making the Euro crisis has occasioned are posing new questions of the temporal framework by which decisions in a democracy are contested. Modern democratic politics has typically been a politics of rhythm. As political improvisation comes to the fore, so the rhythms of democratic politics are put under strain. How political contestation might be achieved under these conditions will be one of our guiding questions.

A useful way to characterise the political handling of the Euro crisis is to speak of decision-making of a discretionary kind. By this I refer to measures 
which exceed established rules and norms, either in the sense that these are deliberately set aside, or in the sense that they are necessarily transcended because they weakly cover the situation at hand. These rules and norms may be codified or tacit, and may concern the substance of particular policy regimes or the mechanisms by which decisions are arrived at. ${ }^{1}$ Examples of discretionary decision-making in this period include the series of ad hoc measures used to restore market stability from 2010 onwards (the European Financial Stability Facility, the European Stability Mechanism, aid packages to particular countries, and the Fiscal Compact) as well as the procedural improvisations that have facilitated these (notably the concentration of decision-making in the European Council, and the expanding role of the European Central Bank (ECB)). Unconventional moves of this kind have been rationalised as necessary adaptations to the pressures of crisis exceptional times demanding exceptional measures. 'Emergency politics' of this kind has been the stand-out feature of the crisis response so far (White, forthcoming).

Discretionary decision-making is not without its merits. If a particular set of rules is wrong-headed, setting them aside may have much to commend it. If unforeseen situations arise, there may be few rules to refer to. More generally, even in the well-designed polity, an element of discretion vis-à-vis rules and norms may be ineradicable. Accompanied by a considered weighing of options, one might sometimes wish to applaud the exercise of discretion as the exercise of judgement, particularly when made evaluable through a public debate in which justifications are advanced. And with its reflexive attitude towards routinized practice, one might see it as a welcome

\footnotetext{
${ }^{1}$ An extended treatment of the concept of 'discretion' would need to pursue these distinctions systematically; for the purposes of the present discussion, these varieties of discretion can be considered as one. I note in passing that, particularly in the international setting where the reach of existing rules and norms may be disputed, the extent to which actors are choosing to exercise discretion or cannot but do so may be contentious.
} 
reminder of the revisability of our political commitments - an invitation to question standard ways of doing things and to retain a sense of political possibility.

But whatever its possible appeal, and whether pursued in good faith or bad, discretionary decision-making raises major problems for political contestation. ${ }^{2}$ More specifically, it does so when exercised not in forums of public debate such as legislatures, where public contestation is structurally encouraged, but by governments and administrative bodies acting with relative autonomy. ${ }^{3}$ As I shall argue, executive-led discretion generates sharp asymmetries between decision-makers on the one hand and those who would scrutinise them on the other. Many of these have a temporal quality. Discretionary politics tends towards a politics without rhythm, in which those who would contest decision-making are perpetually liable to be left harried, disorganised, and caught by surprise. Something of this kind is visible in Europe today, and to the extent that EU decision-making is still marked by rhythms, these intersect only sporadically with the rhythms of parliamentary politics (be it those of the electoral cycle or of legislative scrutiny) and, given the plurality of political systems that compose the EU, these latter intersect only sporadically with one another. This lack of synchrony weakens political opposition, and allows it to be easily cast as voicing parochial grievances rather than principled critique of generalisable significance.

One may be tempted to see these as temporary problems, characteristic of the EU in an exceptional period in which the old frameworks are being replaced by the new. That a more predictable, rule-bound order is under construction seems to be the hope of many, including some of the institutional actors of the

\footnotetext{
2 It also raises major questions for the rule of law, though these are not our focus here: see Dyzenhaus 2006; Scheuerman 2004.

3 I will not discuss judicial discretion: for one account focused on the European Court of Justice, see Lindseth 2010, Chapter 4.
} 
EU itself (Commission 2012: 13). ${ }^{4}$ But there are various reasons to be sceptical. One is that the specifics of the new order under construction seem to leave many opportunities available for the exercise of discretion (Menéndez 2013; cf. Scharpf 2014). Another is that discretionary decisionmaking has an established place in the history of European integration. Notwithstanding that this process is often narrated as one of rule-formation and ever greater constraints on government autonomy, the emergence of the EU coincides with the increasing independence of administrative actors from the traditional organs of democratic control (Müller 2012) - indeed, it is sometimes said to be symptomatic thereof (Lindseth 2010). ${ }^{5}$ More widely still, executive discretion is arguably an increasingly prominent feature of western politics more generally (Scheuerman 2004; Ackerman 2010). It is widespread in North America as much as the EU. Any renewal of the possibilities for political contestation would seem to require more than simply the patience to outlive the Euro crisis. As I shall suggest in conclusion, an effective response is likely to involve seeking to strengthen and synchronise the rhythms of parliamentary politics, as well as being receptive to forms of political opposition emerging from civil society which are less reliant on the rhythms that discretionary decision-making subverts.

\footnotetext{
${ }^{4}$ However appealing a discretionary regime may be to national governments, they too have reason to seek a more rule-based order insofar as this makes the exercise of power a little less brazen, a little more anonymous.

${ }^{5}$ Lindseth offers a useful historical account of rising executive power in the EU as reflecting a wider 'post-war constitutional settlement of administrative governance' evolving at the national level first and foremost. I am less convinced than Lindseth that this settlement was normatively well-grounded. Note also that the rise of executive power is not identical to the rise of executive discretion.
} 


\section{Asymmetries of a Politics without Rhythm}

Let us begin with some general reflections about the relationship between political contestation, time, and discretionary politics. It has been observed that representative democracy as we know it relies on a minimum of periodicity (e.g. Linz 1998; Chesneaux 2000: 409-10). We see this in a range of institutional devices. Parliamentary timetables offer the possibility for ordered and well-prepared debates on new legislation and the recurrent interrogation of ministers. Electoral cycles express the capacity of citizens to cast judgement on their representatives at regular intervals and revise their political priorities. Fixed or pre-announced election dates allow political parties to organise campaigns and the media to analyse their manifestos. These temporal patterns introduce predictability into politics, and ensure that decisions can be both contested and revisited. Often the pulse of these events stretches out over weeks, months or years, as though meaningful deliberation and debate requires not only regularity but an unhurried pace (Wolin 1997). In one form or another, representative democracy has been closely associated with rhythm. ${ }^{6}$

Discretionary politics by contrast, understood as decision-makers' willingness to act independently of rules and norms, in its pure form is likely to be a politics without rhythm. Decisions which are unconstrained in this way will generally resist being located in an identifiable temporal pattern. I say generally because traces of periodicity may persist due to the influence of noninstitutional rhythms: where there are sharply defined business cycles, for instance, or cycles associated with the natural world (e.g. climatic), these may exercise their own structuring effect. But because such rhythms are plural, and a human choice concerning which to prioritise at a given moment will

${ }^{6}$ On the concept of rhythm and its wider application in the social sciences, see Young and Schuller 1988, pp.13ff. 
always be needed, they do not promise anything like the same degree of predictability. In the absence of institutions able to impose rhythms, the intervals of politics will tend to become irregular and uncertain. Though generalisations are inherently difficult, one can imagine a discretion-based political model will typically display such features as snap decisions, arbitrary ultimatums, indefinite mandates, and policy regimes of unknown duration.

There are several respects in which the possibilities for political contestation are attenuated when decision-making decouples itself from the rhythms of representative democracy. Such a condition entails significant asymmetries between those taking decisions on the one hand (e.g. executives and administrative agencies) and voices of opposition on the other (e.g. parties in the legislature, or movements and individuals in civil society). ${ }^{7}$ First, oppositions are at a significant disadvantage in terms of initiative. The power of timing is an important one in politics (Schedler and Santiso 1998), yet one that institutionalised rhythms go some way to neutralizing. In the absence of such rhythms, those who lack the power of timing will find themselves recurrently taken by surprise and forced to react to initiatives post hoc. Observers note that executives enjoy a 'first-mover advantage' even in relatively rule-bound political orders (Ackerman 2010: 40): that advantage increases insofar as other organs of state and society lack predictable rhythms around which to organise themselves and shape decision-making.

Second, oppositions will be at a disadvantage in terms of their ability to set the tempo of events. Discretionary decision-making is likely to be fast-paced (executive discretion being preferred often precisely for its speed), with the effect that oppositions will find themselves forced to act quickly. In the absence of binding procedures, they will lack the ability to alleviate whatever

7 This holds particularly in a context where citizens have been socialized to expect these rhythms. 
time pressures are placed on them by appeal to a standardised timetable. ${ }^{8}$ And if acting quickly is the condition of having influence at all, in seeking to accelerate their activities they may sacrifice the very virtues of debate and deliberation for which their participation might be welcomed (Scheuerman 2004).

Third, to the extent that policy-making departs from the typical forms of representative democracy, it may be difficult to establish what kinds of decision are being taken, and hence what kind of opposition is appropriate. Knowledge of the policy essentials will be sharply imbalanced. It may be difficult, for instance, to distinguish initiatives intended to create merely temporary arrangements from those intended to forge permanent ones. What counts as an exception to an enduring norm, and what counts as a new beginning, may be ambiguous. If the time horizons associated with a particular proposal are uncertain, as an abbreviated process of scrutiny may dictate, it will be unclear whether to contest that policy or tolerate it. This ambiguity may in turn make it difficult to generate public and media interest, even where long-term implications are suspected. Who is responsible for decisions may also become harder to establish the more they are taken unconventionally and unpredictably. Again, it becomes difficult for critical actors to know where to focus their efforts.

Fourth, not only the practicalities of opposition but its legitimacy may be compromised in the context of a discretion-based regime. Where no regular temporal slots have been reserved for it, opposition may come to seem decadent - a brake on effective and efficient decision-making. The rhetoric of emergency is easily deployed to this effect once the possibility of breaking or

\footnotetext{
${ }^{8}$ Sometimes they will also face the opposite problem: that of resisting the delaying tactics of decision-makers, and of finding opportune moments to contest and raise public awareness of 'non-decisions'. I leave these possibilities aside here, but they should be regarded as significant parallel phenomena, underplayed by proponents of the 'social acceleration' thesis discussed below.
} 
suspending the rhythms of representative democracy has been established, and when pressing external pressures that demand quick response can be cited. Opposition voices may find it correspondingly more difficult to assert their right to be heard. Where decision-makers do seek a dose of public legitimacy, it may well take plebiscitary form, with a direct appeal to 'public opinion' that bypasses political parties and other mechanisms of organised deliberation, with polling timed such that the figures are favourable. ${ }^{9}$

As these brief general reflections indicate, discretionary decision-making, as a politics without rhythm, engenders asymmetries likely to weaken contestation. Opposition is likely to take the form of reactive and abbreviated dissent, weak in its effectiveness and questioned in its legitimacy. One need scarcely add that in such circumstances strong opposition may be more necessary than ever, since decision-making which is pursued in irregular fashion may very well be of poor quality and a worthy target of contestation. It risks being capricious, weakly informed by the systematic consideration of alternatives, and weakly supported by public justification. That these irregular methods may in many cases be used precisely to pursue policies marking a sharp rupture with the status quo further raises the stakes and adds to the burdens of scrutiny facing opposition actors.

Whether contemporary Europe in the age of the Euro crisis has reached anything approaching this condition is the topic of the next section. It is worth highlighting before continuing though that wider tendencies towards this condition have been noted by a number of scholars of western politics. The de-structuring of the rhythms of representative democracy are evident, in one author's words, in the way 'liberal democratic lawmaking increasingly consists of vague and open-ended legal resolutions, exceptional and emergency norms delegating vast discretionary power to the executive and

${ }^{9}$ On 'poll-government', see Chesneaux 2000: 409. 
various administrative bodies, and poorly crafted statutes possessing a limited half-life' (Scheuerman 2004: 56). Emphasizing particularly the implications of discretionary decision-making for the rule of law, the same author describes the weakening of 'a commitment to general, clear, relatively stable, prospective general rules' (Scheuerman 2004: xvii) and moves away from legal stability or evolution towards serial ruptures and ad hoc fixes (cf. Ackerman 2010). ${ }^{10}$

Importantly, many such arguments see these tendencies as symptomatic of a deeper asymmetry between political institutions and the market economy. If representative democracy struggles to maintain its rhythms, in this view it is because increasingly it is subject to the uncertainty and high-speed change associated with other social systems, notably contemporary financial capitalism (Scheuerman 2004; Rosa 2003, 2013; Wolin 1997; McIvor 2011). Jessop speaks in this context of 'the state's loss of time sovereignty' (Jessop 2009: 154), as decision-makers are forced to contend with such nebulous and volatile phenomena as investor confidence, which fluctuate unpredictably and resist responses based on stable rules and regularized procedures, and which also raise the stakes of decision-making sufficiently high that the automatic application of pre-set rules could have unacceptably negative repercussions (cf. familiar notions of banks 'too big to fail'). Decision-makers would then seem to have two options: either to abdicate responsibility for regulating the market economy (as libertarians would prescribe), or particularly when a crisis suggests such an approach is inadequate - to reassert themselves, not through the conventional (slow, rhythmic) channels of representative democracy but by means of 'fast policy' (Jessop 2009) made

\footnotetext{
10 For an interesting effort to find the positive in these developments, see Posner and Vermeule 2011. Their emphasis on the potential for political rather than legal constraints on executive power is promising: their suggestion that plebiscitary mechanisms backed by media commentary are adequate to this task, and indeed largely perform it, seems complacent however.
} 
by relatively autonomous executives and functional agencies, designed to respond quickly to fast-moving and unpredictable events.

One should be cautious with the determinist implications of these arguments from 'social acceleration'. They are nonetheless a useful reminder that the exercise of executive discretion is by no means necessarily indicative of unlimited executive power. Whatever their position of strength vis-à-vis voices of political opposition, executives themselves may be constrained by conditions outside their control, and encouraged in their adoption of discretionary measures by powerful organized interests. ${ }^{11}$

\section{Europe's Fragmented Dissent}

Does the Europe of the Euro crisis display the hallmarks of a politics without rhythm? In its pure form, evidently not. The member states of the EU retain the electoral cycles characteristic of representative democracy, supplemented by that of the European Parliament, while some of the institutions peculiar to the EU - notably the Commission - have their own rhythms of appointment as well as timetables of decision-making. ${ }^{12}$ Nor has any of these institutions been wholly excluded from the handling of the crisis: each, if only formally, has exercised certain powers.

However, it does seem accurate to suggest the key moments of decisionmaking in recent years have been markedly unpredictable and irregular. One sees this expressed in the preponderance of heads-of-government meetings outside the EU framework, that is, ungoverned by procedural timetables, as well as in the prominence of the executive-composed European Council as the

\footnotetext{
${ }^{11}$ In a large, polycentric polity such as the EU, executive power is further compromised by long chains of bureaucratic command separating decision from implementation.

12 On some such rhythms of EU administration, see Ekengren 2002.
} 
EU's pre-eminent decision-making forum, in place of a model by which it 'codecides' with the Parliament (Dawson and de Witte 2013). One also observes it, more impressionistically, in specific decision-making sequences producing outcomes largely unpredicted at the time - for example the fall of the Berlusconi government in autumn 2011 under pressure from the European Council in general and certain members in particular (acting in turn partly under pressure from the bond markets). Such irregular forms of decisionmaking generate many of the asymmetries for opposition previously described. The persisting rhythms of representative democracy, such that they are, have tended to intersect weakly with the key moments of decisionmaking. Only briefly, for instance, have legislatures been able to debate the merits of particular initiatives, their timetables compressed and distorted. Only occasionally has an election coincided with a major step in the crisis response such that decision-making could be meaningfully contested. The usual rhythms of democratic politics have thus been relevant to the course of events only sporadically - and indeed sometimes appear deliberately marginalized. Furthermore, the legitimacy of parliamentary dissent has also frequently been queried through the use of emergency rhetoric (White, forthcoming). The possibilities for political contestation have been correspondingly limited. ${ }^{13}$

One sees the subversion of these rhythms in the suddenness with which legislatures are presented with detailed policy measures to scrutinize and the speed with which they are required to conclude deliberation. Repeatedly one sees national executives, in the name of decisive action to confront market pressure, coordinating in informal settings to produce deals requiring

\footnotetext{
${ }^{13}$ Not all these developments post-date the Euro crisis: concerns about 'deparliamentarisation' are new neither in the field of EU research nor comparative politics more generally (see e.g. Weiler 1999: 266; Curtin 2009).
} 
approval to an early deadline. ${ }^{14}$ The EU-sponsored austerity measures advanced by Mario Monti's Italian government in late 2011 conform to the 'fast policy' model, with sharp policy shifts drawn up in response to high borrowing costs, and parliamentarians pressured to approve the measures at speed. Approval or a full-scale effort to bring down the government have often appeared to be the only options left before the national legislature (Dawson and de Witte 2013; cf. Scharpf 2014). Transnational aid packages have produced similar pressures in both the contributing and receiving countries: not untypical was when the German Bundestag in late November 2012 was given less than 48 hours to approve a financial aid package for Greece agreed by Eurozone finance ministers and the IMF. ${ }^{15}$ As well as curtailing the time available for meaningful scrutiny and deliberation, these moves encourage complaints about procedure which threaten further to crowd out discussion of substance.

The EU is often pictured as the paradigmatic slow organisation, in which decisions are reached sluggishly or not at all. ${ }^{16}$ In this period of crisis we see the capacity of its key institutions to move quickly. Yet one risks an equally one-sided account if one dwells purely on speed. Irregularity is the key observation: action proceeding in fits and starts, with accelerated ratification processes following sometimes quite extended periods of intergovernmental negotiation. Certainly, one should be careful not to see legislatures as mere victims: they too may successfully be able to play discretionary 'time games' with other institutions (Goetz 2009). But to the extent that they do so, one can

\footnotetext{
14 On 'deadlinification' as a broader feature of EU rule, see Ekengren 2002: 128. On the phenomenon of intergovernmental 'breakfast meetings': Puetter 2012.

15 Executive agreement was reached on Tuesday 27 November 2012; the Bundestag was expected to vote on it by Friday $30^{\text {th }}$. Several parliamentarians objected, and the Left Party for the same reason voted against. That the package was no mere technical measure but raised wider normative questions is suggested by the fact it was opposed also from the Greek side by Syriza. 16 Drawing on the stereotype, see The Economist, 'The Sleepwalkers', 25 May 2013.
} 
expect them to come to look less like deliberative chambers that contest public policy and more like corporate actors pursuing institutional interests.

The reduced relevance of the rhythms of representative democracy can be seen also in electoral politics. That there can be no guarantee a general election falls at a critical juncture in a polity's existence is of course one of the wider short-comings of representative democracy. The lack of opportunity for European Parliamentary elections directly to impinge on the Euro crisis before mid-2014 is in many ways simply bad luck - though it is noteworthy that the other EU institutions have felt entitled to press ahead with fundamental changes to the EU's make-up irrespective of this. What is less down to misfortune is the timing of key decisions by governments so as to avoid electoral repercussions where possible. Announcements concerning austerity measures - one of the main pillars of Europe's crisis response - have frequently been postponed until after national elections, such that their scale and the details of their effects are absent from electoral debates. The phenomenon of out-of-cycle budgetary announcements, issued when they are least likely to be strongly contested (i.e. just after an election), has been evident in several member-states. One might describe this as 'rhythm management ${ }^{\prime 17}$ - an expression of the wider power of timing and initiative enjoyed by executives. ${ }^{18}$

Note also the phenomenon of new policy regimes of uncertain duration, which further complicate the task of political opposition. The extent to which the ECB's policy (since September 2012) of buying the bonds of indebted Eurozone member states is a long-term innovation or a short-term measure is

\footnotetext{
17 The manipulation of rhythm is at least as problematic as its absence, as it can allow misleading expectations about influence to be maintained.

18 At the EU level, the scope for executive powers to use timing as a resource is somewhat constrained by their need to coordinate with one another. Still, one can expect member-state governments to accommodate each others' timing concerns where possible, and these external constraints, such that they are, can in turn be a convenient justification for side-stepping legislative rhythms and seizing 'windows of opportunity' when they arise (cf. Ekengren 2002).
} 
unclear, as is the more general role of the ECB in the future of Eurozone administration (cf. Schelkle 2014). ${ }^{19}$ If the status of a policy regime, its timetable of reappraisal, and the role of its initiator is unclear, strategies of response are correspondingly hard to formulate.

Some of these discrepancies between decision-making and the temporality of political contestation can be put down to a period of exceptional discretion as Europe comes to terms with its crisis. While this might very well be normatively problematic nonetheless, it could at least be regarded as an interim condition, before a more structured political order anchored in the existing EU institutions emerges. We have already noted the possibility that whatever new order emerges in the coming years may be as susceptible as that preceding it to discretionary handling where it suits powerful actors. Even if we discount this possibility however, it is worth noting that the new rhythms of decision-making which seem poised to develop - those of the European Semester, for instance - do not correlate in any systematic way with the rhythms of democratic politics as they stand today. If, as it is proposed, the Commission is to scrutinize and make demands of national budgets on an annual basis, it is difficult to see how parliamentary elections spaced out over a much wider period will have influence on the process, except on an occasional and arbitrary basis. ${ }^{20}$ Even legislative politics - both at European or national level - would need to make significant adaptations to coalesce with these rhythms. In other words, while EU decision-making may

\footnotetext{
${ }^{19}$ Note also that the policy as announced in August 2012 - the Outright Monetary Transactions (OMT) scheme - and as implemented in the months following diverge in important respects, chiefly to do with conditionality requirements, leaving uncertainty as to what the policy actually involves. (This was clearly visible when the Bundesgericht examined the legality of the policy in June 2013: http://euobserver.com/economic/120465.)

20 In an interesting discussion of EU temporality, Goetz asks 'how does the EU tick?' (Goetz 2009). Perhaps such a formulation already underestimates the discretionary aspects of European executive decision-making however, particularly in the Council and in extra-EU ad hoc forums, where the regular rhythm of a ticking clock is hard to identify, while the rhythms of other institutions are often peripheral to decision-making.
} 
conceivably become more regularized, there is no reason to expect it to synchronize better with the rhythms of democratic politics.

It is furthermore the case that Europe's democratic rhythms exist in the plural and lack synchrony with one another. Each EU member-state operates to a different electoral timetable and is shaped by different cadences of legislative scrutiny. Goetz emphasizes the heterotemporality of EU politics, that is, the absence of a dominant political cycle (Goetz 2009). The effect for political contestation is that the forces of opposition are divided across different 'timezones'. Although debates in the public spheres of EU member-states may to some degree parallel one another, even respond to one another (cf. Kriesi and Grande 2014), the timing of their institutionalized expression is splintered.

It may be tempting to see this as desirable. The fact that somewhere in the $\mathrm{EU}$, in one member state or another, there is always an election around the corner might be thought to exercise a useful constraint on the decisions of the Council, ensuring that critical voices of public opinion are never wholly discounted from its considerations. It might also be thought a possible source of mobilization: as revolutionary movements around the world have shown over the last few decades, when opposition is successfully marshalled in one country it can build momentum in others, leading to the famous 'domino effect'. Opposition which is cumulative rather than instantaneous would seem to have something going for it.

These cross-cutting temporal divisions are more likely a weakness however. First, such fragmented oppositions may be less effective. They will struggle to impose a rhythm onto decision-makers disposed towards discretionary action, since they have no single rhythm of their own to offer. Second, that they are localized in this way makes them prone to being cast as parochial. The non-synchronisation of political opposition in Europe contributes to the 
'nationalization' of the crisis, whereby those resisting austerity measures tend to be portrayed as responding to local concerns, perhaps defending local interests - for example those of a 'debtor country' - rather than voicing principled critiques in the name of a common European interest. While we tend to think of this as a problem of the absence of genuinely transnational political actors such as pan-European parties, it can equally be seen as a problem of non-coordination between national actors, due to their anchoring in different institutional rhythms. Spatial fragmentation accompanies temporal fragmentation. Herein lies one of the shortcomings of suggestions that Europe's national institutions in broadly their current form can be adequate sites for the political contestation of EU decision-making. ${ }^{21}$

The argument is frequently made that the Euro crisis is already leading to the EU's politicization (De Wilde and Zürn 2012). If politicization here means no more than the salience in public discourse of matters European and a measure of polarisation and conflict in their appraisal (cf. Kriesi and Grande 2014), the point may have validity - though one would still need to reckon with the likelihood that large numbers of EU citizens are oblivious or indifferent to these developments and that politicisation is therefore quite uneven in its reach (Hurrelmann, Gora and Wagner 2013; White 2010, 2011). Any normatively appealing concept of politicization surely needs however to go beyond the mere fact of division to consider how far it is shaped by claims made in the name of Europe as a whole. Conflicts which pit territorial subunits of the EU against one another - in the idiom of the crisis, debtor states against creditor states - lead to decision-making being contested only on the question of whose parochial interests it serves, not on the deeper questions of principle that may be at stake (e.g. how interests should be defined and

21 On the potential of national parliaments, see Cooper 2012. 
weighed). Oppositions which are temporally fragmented fit all too easily into this nation-shaped mould.

\section{Timing Opposition}

Discretionary forms of rule seem to raise particular challenges then for the ability of dissenting voices to contest the substance of EU decision-making. Moments of decision-making become irregular and unpredictable, leaving opposition at a significant disadvantage. Though the rhythms characteristic of representative democracy do not disappear, they are marginalized, disrupted and squeezed, and lack synchrony with one another, leaving political oppositions weak and fragmented. It is, moreover, by no means clear that this is a temporary condition: nothing about the way the EU is being transformed suggests this, and the tendencies may in any case be global ones. This should be a source of unease even for those who endorse the decisions produced in this way: weak opposition undermines legitimacy and raises the prospect of non-compliance. As Peter Mair famously noted, 'once we cannot organize opposition in the EU, we are then almost forced to organize opposition to the EU' (Mair 2007: 7).

While executive discretion is by no means the only challenge facing political contestation in today's EU - problems of ideological hegemony and citizen disenchantment may be just as central - it is worth considering how political opposition might evolve to contend with it. Based on the foregoing analysis, one will naturally look first to the possibilities for enhancing the EU's political rhythms. In part this might involve efforts to make executive decisionmaking more rule-bound and predictable by strengthening the constraints within which it must operate - essentially a rule-of-law project. In part it 
might involve efforts to harmonize and strengthen the EU's rhythms of opposition. If the political will to support them were available, one might point to a number of institutional 'solutions'. Holding the national elections of member states on the same day would seem one way to advance the synchronisation of opposition, and would entail only a marginal loss of decision-making authority at the national level: existing processes would be largely preserved. National referenda could be likewise synchronized, notwithstanding the fact not all member states are likely to submit future decisions on European integration to a popular vote. Perhaps there is more scope for coordination at the party-political level, since this is feasible within current institutional arrangements. National parties might decide to synchronize certain policy statements, enhancing the media attention they receive, or call for parallel debates in national parliaments. And one might still look for ways of strengthening the European Parliament, such that its rhythms of election and debate can better impose themselves on decisionmaking. Increasing its powers vis-à-vis the Council, even embedding the latter within it, has much to commend it in principle. More modestly, one might simply seek ways to integrate Parliamentary time with the emerging rhythms of the European Semester, such that debates in the legislature can have influence on the latter - or such that it can be more readily observed if they do not. ${ }^{22}$

Moves to strengthen the rhythms of representative democracy do not however address the fact that these rhythms always risk marginalisation. It is one of the basic limitations of legislatures in their current form that, being dependent on rhythms, they are vulnerable to the kind of 'rhythm management' earlier described, as well as to the time pressures that theorists

${ }^{22}$ The Commission 'Blueprint' notes the desirability of flanking the European Semester timetable with two European Parliamentary debates (Commission 2012: 36), though it is unclear the extent to which meaningful contestation of decision-making is the goal. 
of social acceleration describe. It seems important therefore also to recognize forms of political opposition which are independent of such rhythms. ${ }^{23}$ Extraparliamentary movements in particular have the flexibility to time their actions so as better to respond to discretionary decision-making, and to do so in synchronized fashion. The Euro crisis has seen a number of protests and strikes coordinated transnationally, in a way that amplifies their public visibility, if not ultimately their political effectiveness. ${ }^{24}$ Petitions likewise have the capacity to offer moments of synchronized opposition: this is one of the potential qualities of the European Citizens Initiative, whatever its other limitations. The ICTs offer forms of coordinated politics that rival the economic domain in spontaneity and speed of action. All these forms of opposition have an unpredictable and elastic quality that makes them well suited to responding to discretionary rule.

If extra-parliamentary opposition is nonetheless too remote from decisionmaking to be consistently influential, and too disorganized and spontaneous to be reliably deliberative, one might ask whether there are not ways of reconfiguring legislative institutions so as to incorporate some of the same elasticity. How might one design non-rhythmic democratic institutions, so as better to contend with the discretionary manoeuvres of executives? Establishing the possibility of snap elections should a certain threshold of public support be crossed would be one approach. Oddball proposals such as randomizing the timing of elections so they become less easy for executives to discount from their calculations would be another. Certainly at a theoretical level it seems important to explore the possibility that democracy and rhythm should part company.

\footnotetext{
23 On the distinctive temporal logic of 'agitation': Wolin 2005; on the competing attractions of political routine and spontaneity: Goodin 1998: 48.

${ }^{24}$ See e.g. the coordinated strikes of 14 November 2012 in Spain, Portugal, Greece, Italy, France, and Belgium, as reported in the New York Times ('Workers Across Europe Synchronise Protests', 14 November 2012).
} 
Aside from questions of realistic probability, such ideas might seem to leave the EU at risk of paralysis in times of genuine crisis. Are there not circumstances when a decisive executive actor should be able to act with discretion, unencumbered by the whims of political opposition? It may be possible to accept this while still looking for ways of placing constraints on the scope and duration of unconventional rule. Requiring that the use of special powers face parliamentary review at regular intervals (perhaps over a period of just days or weeks), and meet ever higher thresholds of parliamentary support to be continued, may go some way to checking the exercise of discretion without erasing it (cf. Ackerman 2010).

Coming to terms with discretionary decision-making is likely to require imaginative thinking. As a preliminary step I hope to have indicated some of the challenges facing political opposition in today's EU. The rise of executive power, and with it the marginalization and compression of the rhythms of representative democracy, are neither wholly new tendencies nor ones unique to this setting. The Euro crisis reveals them with some clarity however, and has the potential to exacerbate them in the long term. Politicizing Europe in a way that enhances rather than detracts from the legitimacy of its decisionmaking would seem to require the strengthening of its political opposition, either through the consolidation of the institutional rhythms it has traditionally depended on, or through the emergence of new formulas that lighten this dependence. 


\section{References}

Ackerman, Bruce (2010), The Decline and Fall of the American Republic (Cambridge MA: Harvard UP).

Chesneaux, Jean (2000), 'Speed and democracy: an uneasy dialogue', Social Science Information 39 (3), pp.407-20.

Commission, The European (2012), 'A Blueprint for a Deep and Genuine Economic and Monetary Union: Launching a European Debate', COM(2012) 777 final/2, 30th November (Brussels: European Commission).

Cooper, Ian (2012), 'A "Virtual Third Chamber" for the European Union? National Parliaments after the Treaty of Lisbon', West European Politics, 35 (3), pp.441-65.

Curtin, Deidre (2009), Executive Power of the European Union. Law, Practices and the Living Constitution (Oxford: OUP).

De Wilde, Pieter and Michael Zürn (2012), 'Can the Politicization of European Integration be Reversed?', Journal of Common Market Studies 50 (S1).

Dawson, Mark and Floris de Witte (2013), 'Constitutional Balance in the EU after the Euro-crisis', Modern Law Review (forthcoming).

Dyzenhaus, David (2006), The Constitution of Law: Legality in a Time of Emergency (Cambridge: CUP).

Ekengren, Magnus (2002), The Time of European Governance (Manchester: MUP).

Goetz, Klaus. H. (2009) 'How does the EU tick? Five propositions on political time', Journal of European Public Policy 16 (2), pp.202-20.

Goodin, Robert E. (1998), 'Keeping Political Time: The Rhythms of Democracy', International Political Science Review 19 (1), pp.39-54.

Hurrelmann, Achim, Anna Gora and Andrea Wagner (2013), 'The Politicization of European Integration: More than an Elite Affair?', Political Studies 61.

Jessop, Bob (2009), 'The Spatio-Temporal Dynamics of Globalising Capital and their Impact on State Power and Democracy', in Rosa and Scheuerman (eds.) High-Speed Society (University Park: Pennsylvania State UP).

Kriesi, Hanspeter and Edgar Grande (2014), 'Political Debate in a Polarizing Union', in Sara B. Hobolt and Olaf Cramme (eds.), Democratic Politics in a European Union under Stress (Oxford: OUP).

Lindseth, Peter L. (2010), Power and Legitimacy: Reconciling Europe and the Nation-State (Oxford: OUP).

Linz, Juan J. (1998), 'Democracy's Time Constraints', International Political Science Review 19 (1), pp.19-37.

Mair, Peter (2007) 'Political opposition and the European Union', Government \& Opposition 41 (1), pp.1-17.

McIvor, David (2011), 'The Politics of Speed: Connolly, Wolin, and the Prospects for Democratic Citizenship in an Accelerated Polity', Polity 43 (1). 


\section{Politicizing Europe: The Challenge of Executive Discretion}

Menéndez, Agustín José (2013), 'The Existential Crisis of the European Union', German Law Journal 14 (5), pp.453-526.

Müller, Jan-Werner (2012), 'Beyond Militant Democracy?', New Left Review 73, Jan / Feb.

Posner, Eric A. and Adrian Vermeule (2011), The Executive Unbound: After the Madisonian Republic (Oxford: OUP).

Puetter, Uwe (2012),'Europe's Deliberative Intergovernmentalism: The new role of the Council and European Council in EU Economic Governance' Journal of European Public Policy 19 (2), pp.161-178.

Rosa, Hartmut (2003), 'Social Acceleration: Ethical and Political Consequences of a Desynchronized High-speed Society', Constellations 10 (1), pp.3-33.

--- (2013), Social Acceleration: A New Theory of Modernity (New York: Columbia UP).

--- and Scheuerman, William (eds.) (2009), High-Speed Society (University Park: Pennsylvania State UP).

Scharpf, Fritz (2014), 'Political Legitimacy in a Non-optimal Currency Area', in Sara B. Hobolt and Olaf Cramme (eds.), Democratic Politics in a European Union under Stress (Oxford: OUP).

Schedler, Andreas and Javier Santiso (1998), 'Democracy and time: an invitation', International Political Science Review 19 (1), pp.5-18.

Schelkle, Waltraud (2014), 'The Insurance Potential of a Non-optimal Currency Area', in Sara B. Hobolt and Olaf Cramme (eds.), Democratic Politics in a European Union under Stress (Oxford: OUP).

Scheuerman, William (2004), Liberal Democracy and the Social Acceleration of Time (Baltimore: Johns Hopkins).

--- (2001), 'Liberal Democracy and the Empire of Speed,' Polity 34.

Weiler, J. H. H. (1999), The Constitution of Europe: 'Do the New Clothes Have an Emperor?' and Other Essays on European Integration (Cambridge: CUP).

White, Jonathan (forthcoming; online early), 'Emergency Europe', Political Studies.

--- (2011), Political Allegiance after European Integration (Basingstoke: Palgrave Macmillan).

--- (2010), 'European Integration by Daylight’, Comparative European Politics 8 (1), pp.55-73.

Wolin, Sheldon (1997), 'What Time Is It?', Theory \& Event 1.

--- (2005), 'Agitated Times,' Parallax 11, pp.2-11.

Young, Michael and Tom Schuller (1988), The Rhythms of Society (London: Routledge). 


\section{Recent LEQS papers}

Esteve-González, Patricia \& Theilen, Bernd. 'European Integration: Partisan Motives or Economic Benefits?' LEQS Paper No. 71, February 2014

Monastiriotis, Vassilis. 'Origin of FDI and domestic productivity spillovers: does European FDI have a 'productivity advantage' in the ENP countries?' LEQS Paper No. 70, January 2014

Ward-Warmedinger, Melanie \& Macchiarelli, Corrado. 'Transitions in labour market status in the European Union' LEQS Paper No. 69, November 2013

Dani, Marco. 'The 'Partisan Constitution' and the corrosion of European constitutional culture' LEQS Paper No. 68, November 2013

Bronk, Richard \& Jacoby, Wade. 'Avoiding monocultures in the European Union: the case for the mutual recognition of difference in conditions of uncertainty' LEQS Paper No. 67, September 2013

Johnston, Alison, Hancké, Bob \& Pant, Suman. 'Comparative Institutional Advantage in the European Sovereign Debt Crisis' LEQS Paper No. 66, September 2013

Lunz, Patrick. 'What's left of the left? Partisanship and the political economy of labour market reform: why has the social democratic party in Germany liberalised labour markets?' LEQS Paper No. 65, July 2013

Estrin, Saul \& Uvalic, Milica. 'Foreign direct investment into transition economies: Are the Balkans different?' LEQS Paper No. 64, July 2013

Everson, Michelle \& Joerges, Christian. 'Who is the Guardian for Constitutionalism in Europe after the Financial Crisis?' LEQS Paper No. 63, June 2013

Meijers, Maurits. 'The Euro-crisis as a catalyst of the Europeanization of public spheres? A crosstemporal study of the Netherlands and Germany' LEQS Paper No. 62, June 2013

Bugaric, Bojan. 'Europe Against the Left? On Legal Limits to Progressive Politics' LEQS Paper No. 61, May 2013

Somek, Alexander. 'Europe: From emancipation to empowerment' LEQS Paper No. 60, April 2013

Kleine, Mareike. 'Trading Control: National Chiefdoms within International Organizations' LEQS Paper No. 59, March 2013

Aranki, Ted \& Macchiarelli, Corrado. 'Employment Duration and Shifts into Retirement in the EU' LEQS Paper No. 58, February 2013

De Grauwe, Paul. 'Design Failures in the Eurozone: Can they be fixed?' LEQS Paper No. 57, February 2013

Teixeira, Pedro. 'The Tortuous Ways of the Market: Looking at the European Integration of Higher Education from an Economic Perspective' LEQS Paper No. 56, January 2013

Costa-i-Font, Joan. ' Fiscal Federalism and European Health System Decentralization: A Perspective' LEQS Paper No. 55, December 2012

Schelkle, Waltraud. 'Collapsing Worlds and Varieties of welfare capitalism: In search of a new political economy of welfare' LEQS Paper No. 54, November 2012 


\section{LEQS}

European Institute London School of Economics Houghton Street WC2A 2AE London

Email: euroinst.LEQS@lse.ac.uk

http://www2.lse.ac.uk/europeanInstitute/LEQS/Home.aspx

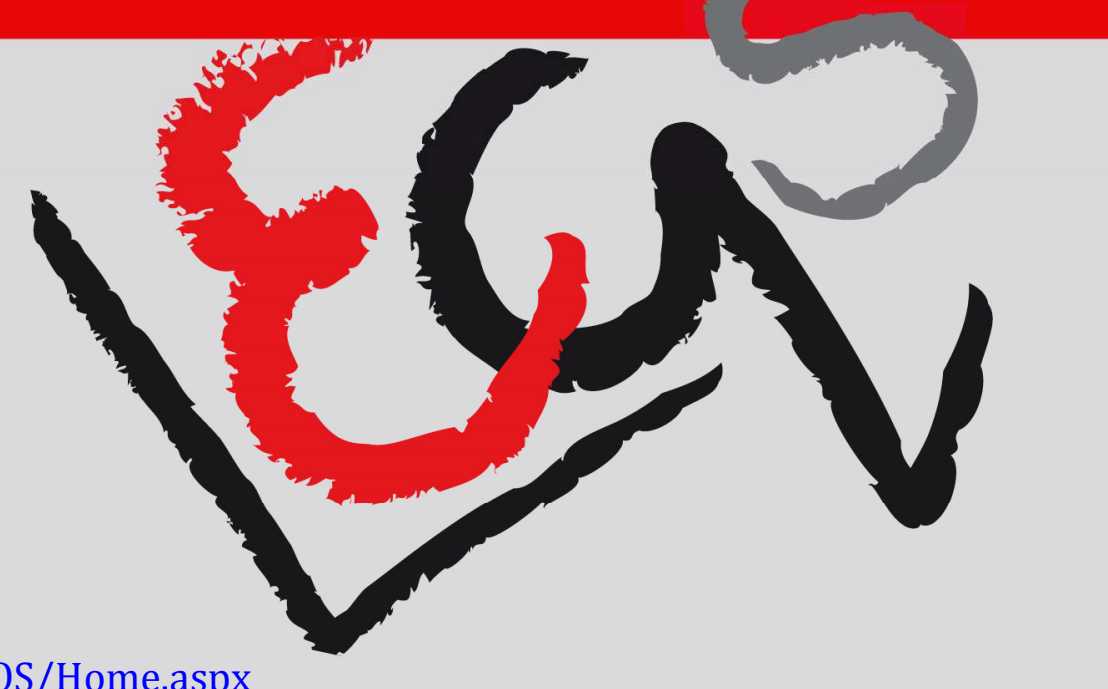

